\title{
Growth, mortality and relative yield per recruit of Japanese scad Decapterus maruadsi (Temminck \& Schlegel, 1842) in the Gulf of Suez, Red Sea, Egypt
}

\author{
Sahar F. Mehanna ${ }^{1}$; Magdy T. Khalil' ${ }^{2}$; Mahmoud H. M. Ahmed ${ }^{3}$; Sameh B. El \\ Kafrawy $^{3}$ and Asaar S. H. El-Sherbeny ${ }^{1}$ \\ 1- National Institute of Oceanography and Fisheries, Fisheries Division, Fish Population \\ Dynamics Dept., Suez, Egypt. \\ 2- Ain Shams University, Faculty of Science, Zoology Dept., Cairo, Egypt \\ 3- National Authority for Remote Sensing and Space Science, Agriculture Applications, \\ Soil and Marine Science Division, Marine Science Dept., Cairo, Egypt. \\ "Asar Elsherbeny@yahoo.com", P.O. Box, 182, Suez, Egypt
}

\section{ABSTRACT}

The stock of Japanese scad Decapterus maruadsi was assessed based on 1864 specimen (combined sexes), collected from the Gulf of Suez during the fishing season 2011/2012. The growth parameters $(\mathrm{L} \infty \& \mathrm{~K})$ have been estimated from length frequency distribution data, and the obtained values were $\mathrm{L} \infty=27.31 \mathrm{~cm} \mathrm{TL}$ and $\mathrm{K}=$ $0.53 / y$. The instantaneous rates of total $(\mathrm{Z})$, natural $(\mathrm{M})$ and fishing $(\mathrm{F})$ mortalities were $1.80,0.61$ and $1.19 / \mathrm{y}$ respectively with exploitation ratio $(\mathrm{E})$ of $0.66 / \mathrm{y}$ which reflects an over exploitation situation. The estimated length at first capture $\left(\mathrm{L}_{\mathrm{c}}\right)$ was $12.2 \mathrm{~cm}$, while the length at first sexual maturity $\left(\mathrm{L}_{\mathrm{m}}\right)$ was $12.3 \mathrm{~cm}$. The relative yield per recruit analysis shows that the stock of $D$. maruadsi is overexploited and needs to develop a management strategy to conserve and optimize its yield.

Keywords: Growth; yield per recruit; Decapterus maruadsi; Gulf of Suez

\section{INTRODUCTION}

The Gulf of Suez is considered as one of the major sources of fish production in the Egyptian sector of the Red Sea as well as in Egypt. Pelagic fishes, caught by purse seine in the Gulf of Suez, represent about $67 \%$ of the total annual fish production from the Gulf; hence they contribute to a major fishery in Egypt. They are mostly small, highly mobile, schooling fish, live in the surface and near-surface waters. The pelagic fish community in the Gulf of Suez consists of Trachurus indicus, Decapterus maruadsi, Rastrelliger kanagurta, Scomber japonicus, Engraulis japonicus, Etrumeus teres and Sardinella gibbosa.

Analysis of annual total Suez Gulf catch and purse seine catch landed during the last fourteen years; from the fishing season 1998/1999 to 2011/2012 revealed that both total and purse seine catches; decreased sharply through the past ten years.

Family Carangidae is considered one of the economically important families in the Gulf of Suez. This family contains more than 200 species of marine fishes, including such well-known forms as the horse mackerels, scads, jacks and pompanos. Horse mackerels in the Gulf of Suez are represented mainly by three species; Arabian scad Trachurus indicus, round scad Decapterus macrosoma and Japanese scad D. maruadsi. They contribute by about $77 \%$ of the purse seine catch; hence they contribute to a major fishery in Egypt (GAFRD, 2012). Despite the great importance of horse mackerels in the Egyptian Red Sea fisheries, a little is known about their dynamics (Sanders and Morgan, 1989 on D. maruadsi; El-Gammal et al., 1995 on T. indicus; Mehanna, 1999a\&b on T. indicus and D. macrosoma; Khalifa and Mehanna, 2005 on the management of carangid fishery in the Gulf of Suez). 
The present study is aimed to estimate the basic parameters required for assessing and managing D. maruadsi stock in the Gulf of Suez.

\section{MATERIALS AND METHODS}

1864 specimens of D. maruadsi were collected from purse seine catches in the Gulf of Suez (Fig. 1), during the period from September 2011 to May 2012. Total length and total weight were measured to the nearest millimeter and 0.1 gram respectively. The length frequency distribution of all specimens of $D$. maruadsi (sexes combined) was arranged in $1.0 \mathrm{~cm}$ length intervals. The FiSAT II software was applied for data analysis (Gayanilo et al., 1997).

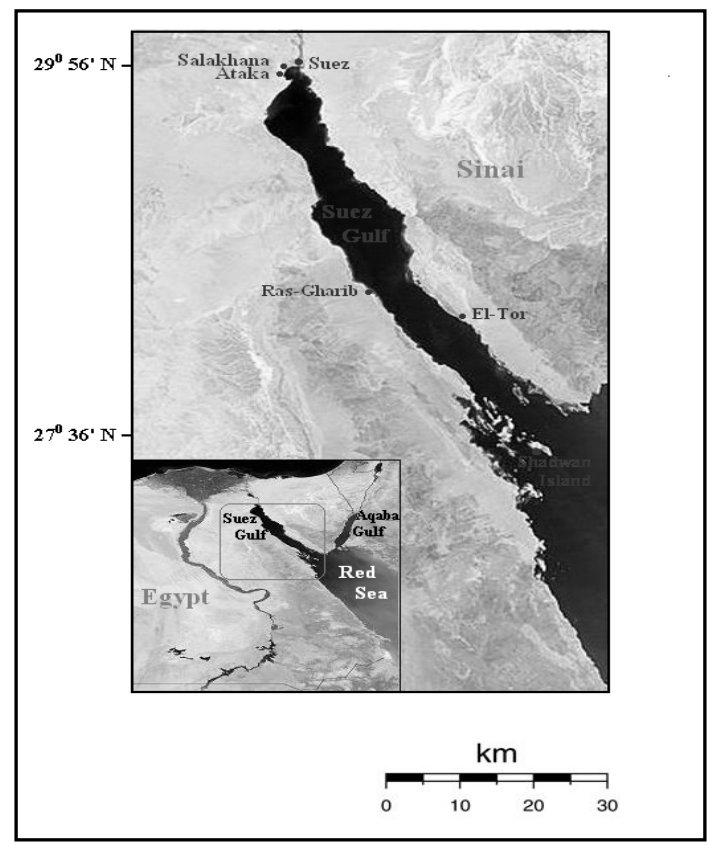

Fig. 1: A map of the Gulf of Suez showing the main four fishing harbors along it Salakhana, Ataka, Ras Gharib and El-Tor.

Length - weight relationship was determined by using the equation $\mathrm{W}=\mathrm{aL}^{\mathrm{b}}$ (Beckman, 1948 and Le Cren, 1951); Where $\mathrm{W}$ is the total weight (g), L is the total length $(\mathrm{cm})$, $a$ and $b$ are constants whose values were estimated by the least square method.

Growth parameters "L $\infty$ and K" were estimated by using the methods of Powell (1979) - Wetherall (1986) and ELEFAN I (Pauly, 1987). The reliability of these growth parameters was tested by Phi-prime " $\varnothing$ '" computed from the equation derived by Pauly and Munro (1984) as $\emptyset^{\prime}=\log _{10} \mathrm{~K}+2 \log _{10} \mathrm{~L}_{\infty}$.

Total mortality coefficient " $Z$ " was calculated by two methods; Jones and Van Zalinge (1981) and Pauly (1983) methods. Natural mortality coefficient "M" was estimated by two methods; Ursin's method (1967) as $\mathrm{M}=\mathrm{W}^{-1 / 3}$ and Pauly's empirical equation (1980) as $\log \mathrm{M}=-0.0066-0.279 \log \mathrm{L}_{\infty}+0.6543 \log \mathrm{K}+0.4634 \log \mathrm{T}$, Where $\mathrm{T}=$ average annual temperature of the stock's habitat in ${ }^{\circ} \mathrm{C}$. Fishing mortality coefficient " $F$ " was estimated as $F=Z-M$. The exploitation ratio " $E$ " was estimated by the formula suggested by Gulland (1971) through the relation $\mathrm{E}=\mathrm{F} / \mathrm{Z}$.

Critical lengths; length at recruitment $\mathrm{L}_{\mathrm{r}}$, length at first capture $\mathrm{L}_{\mathrm{c}}$ and length at first sexual maturity $\mathrm{L}_{\mathrm{m}}$ were determined. $\mathrm{L}_{\mathrm{r}}$ is considered as the smallest fish in the catch; $\mathrm{L}_{\mathrm{c}}$ (the length at which $50 \%$ of the fish retained in the gear) was estimated by 
the analysis of catch curve using the method of Pauly (1984), while $\mathrm{L}_{\mathrm{r}}$ was estimated by fitting the percentage maturity against mid lengths. $\mathrm{L}_{\mathrm{m}}$ was estimated as the point on $\mathrm{X}$-axis corresponding to $50 \%$ point on $\mathrm{Y}$-axis.

Relative yield per recruit (Y/R)' was estimated using the model of Beverton and Holt (1966) as modified by Pauly and Soriano (1986) and incorporated in the FiSAT software package as follows: $(\mathrm{Y} / \mathrm{R})^{\prime}=\mathrm{E} \mathrm{U}^{\mathrm{M} / \mathrm{K}}\left[1-(3 \mathrm{U} / 1+\mathrm{m})+\left(3 \mathrm{U}^{2} / 1+2 \mathrm{~m}\right)-\right.$ $\left.\left(\mathrm{U}^{3} / 1+3 \mathrm{~m}\right)\right]$

Where: $\mathrm{m}=(1-\mathrm{E}) /(\mathrm{M} / \mathrm{K})=(\mathrm{K} / \mathrm{Z})$ and $\mathrm{U}=1-(\mathrm{Lc} / \mathrm{L} \infty)$.

\section{RESULTS AND DISCUSSION}

\section{Length - Weight Relationship}

The measurements of total length and total weight of 1864 specimens of D. maruadsi were used to estimate the length-weight relationship (Fig. 2). The total length ranged between 7.3 and $25.1 \mathrm{~cm}$, while the total weight varied from 4.4 and $141.7 \mathrm{~g}$. The obtained equation was found to be: $\mathrm{W}=0.013 \mathrm{TL}^{2.903}(\mathrm{r}=0.983)$ indicating an isometric growth. This result is in agreement with the only previous work on this species of Sanders and Morgan (1989) who gave $b=3.03$ in the Gulf of Suez.

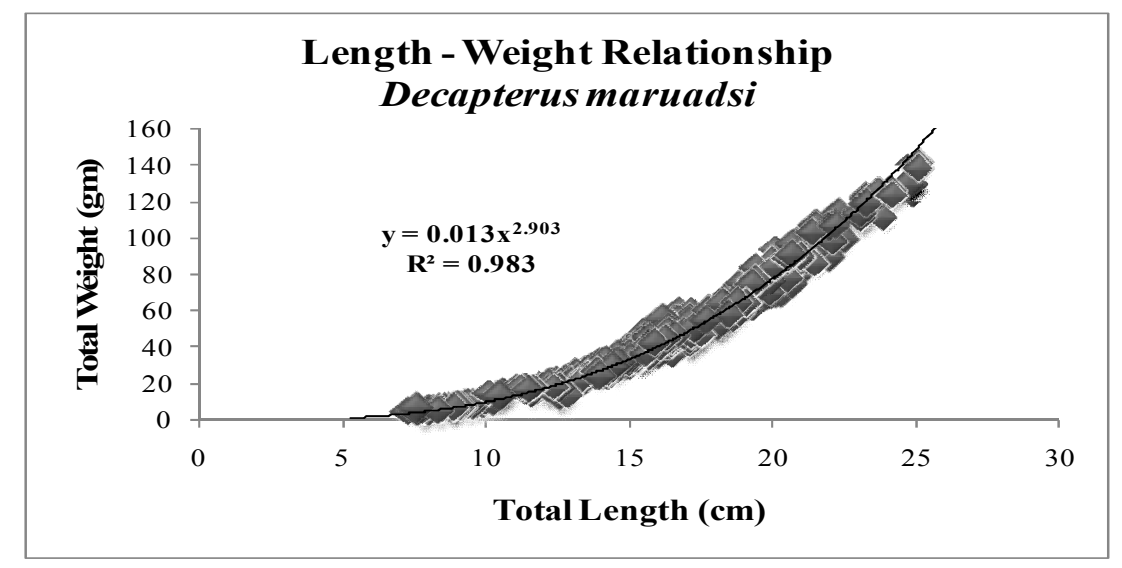

Fig. 2: Length - Weight Relationship of Japanese scad Decapterus maruadsi

\section{Growth Parameters \& Growth Performance Index}

The values of von Bertalanffy constants " $\mathrm{L}_{\infty}$ and $\mathrm{K}$ " estimated by the methods of Powell (1979) - Wetherall (1986) and ELEFAN I (Pauly, 1987) for D. maruadsi, are showed in Fig. 3. It is clear that there is a good agreement between the values of the two applied methods. So, the values obtained by Powell - Wetherall were chosen for subsequent calculations. The obtained values of $\mathrm{L}_{\infty} \& \mathrm{~K}$ for $D$. maruadsi were $27.31 \mathrm{~cm}$ and $0.53 /$ year, respectively and the computed value of $\varnothing^{\prime}$ was 2.60. Sanders and Morgan (1989) had calculated the values of $L_{\infty}$ and $K$ as $25 \mathrm{~cm}$ and $0.41 / y$, respectively for the same species in the Gulf of Sue
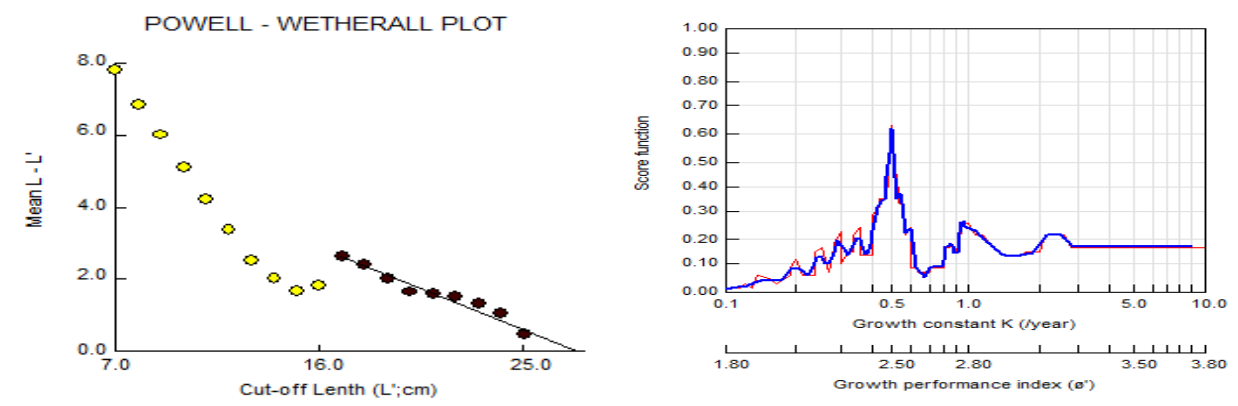

Fig. 3: Powell - Wetherall and ELEFAN I plots of Japanese scad Decapterus maruadsi 


\section{Mortality and Exploitation Rates}

Total mortality coefficient (Z), estimated from two methods; Jones and Van Zalinge (1981) and Pauly (1983) were found to be 1.74 and 1.86/y, respectively (Fig. 4) with a mean value of $1.80 / \mathrm{y}$. The mean value of natural mortality coefficient $(\mathrm{M})$ was $0.61 / \mathrm{year}$, correspondingly the value of fishing mortality coefficient (F) was $1.19 / \mathrm{y}$. The estimated exploitation ratio (E) was 0.66/year, which seemed to be higher than the optimum level of exploitation $(E=0.5)$, this is based on the assumption that a stock is optimally exploited at $E$ $=0.5$ when F equals M (Gulland, 1971). So, this high value of " $E$ " indicating that the stock of D. maruadsi is overexploited. Sanders and Morgan (1989) had estimated the values of Z, M, $\mathrm{F}$ and $\mathrm{E}$ for the same species in the Suez Gulf as $2.3,0.7,1.6$ and $0.7 / \mathrm{y}$, respectively.
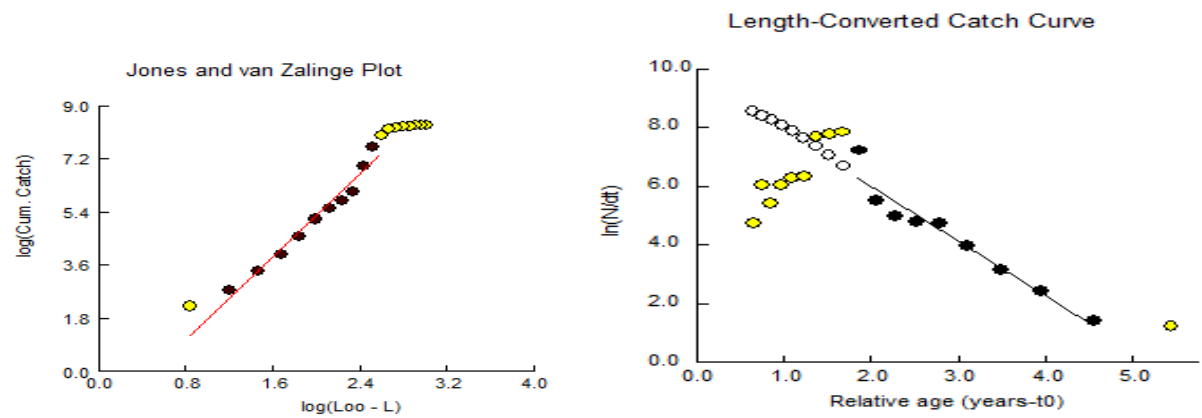

Fig. 4: Cumulative catch curve and Length converted catch curve of Japanese scad Decapterus maruadsi

\section{Critical Lengths}

The obtained value of $\mathrm{L}_{\mathrm{r}}$ for D. maruadsi was $7.3 \mathrm{~cm}$, while the value of $\mathrm{L}_{\mathrm{c}}$ was 12.2 $\mathrm{cm}$, whereas the value of $\mathrm{L}_{\mathrm{m}}$ was $12.3 \mathrm{~cm}$ (Fig. 5). From results, it is clear that the estimated value of $\mathrm{L}_{c}$ was lower than the estimated $\mathrm{L}_{\mathrm{m}}$, which was an evidence of over-fishing that prevent them from spawning at least once before being fished.
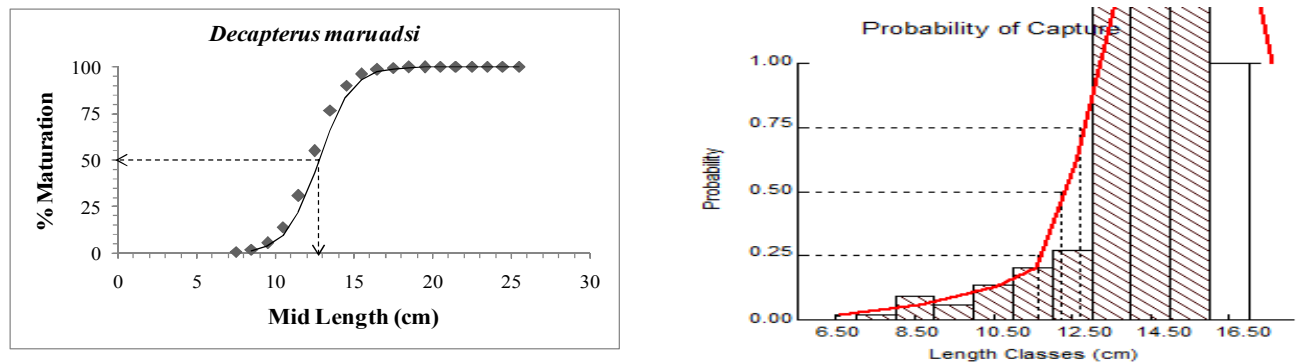

Fig. 5: Lengths at first maturity and at first capture for Japanese scad Decapterus maruadsi

\section{Relative Yield per Recruit}

The exploitation level which will result in a reduction of the unexploited biomass by $50 \%$ " $\mathrm{E}_{0.5}$ ", and the exploitation level which give the maximum relative yield per recruit " $\mathrm{E}_{\max }$ " for D. maruadsi were estimated from the plot of Relative Yield per Recruit (Y'/R) against $E$ that showed in Figure (6). The estimated values of $E_{0.5}$ and $E_{\max }$ were 0.35 and 0.63 , respectively and both values were found to be lower than the value of current exploitation rate (0.66 /year). 


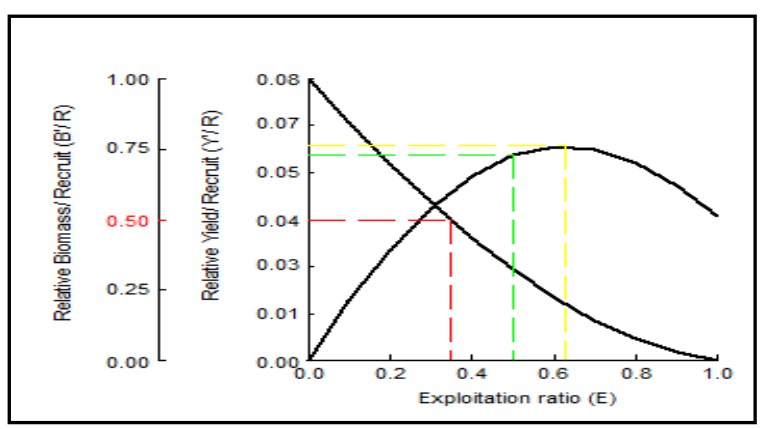

Fig. 6: Relative yield per recruit curve of Japanese scad Decapterus maruadsi

In conclusion, it is clear from results that; not only, the investigated fish species $D$. maruadsi is undergo high values of exploitation rates, where it has "E" higher than 0.5 , but also exceeded the values of $E_{0.5}$. For management purpose, the current exploitation rate of investigated pelagic fish species $D$. maruadsi should be reduced from 0.66 to 0.35 to maintain a sufficient spawning biomass.

\section{REFERENCES}

Beckman, W. C. (1948). The length - weight relationship, factor for conversions between standards and total length and coefficient of condition for seven Michigan fishes. Trans. Amer. Fish. Soc., 75: 273-256.

Beverton, R. J. H. and Holt, S. J. (1966). Manual of methods for fish stock assessment. Part 2. Tables of yield functions. FAO Fish. Tech. Pap./ FAO Doc. (38) Rev. 1: 67pp.

El-Gammal, F. I.; Bebars, M. I. and Tharwat, A. (1995). Age, growth and mortality of horse mackerel, Trachurus indicus from the Gulf of Suez. J. Appl. Sci., 10(3): 420-430.

GAFRD (2012). General Authority for Fish Resources Development. Annual fishery statistics report, Cairo, Egypt. 106pp.

Gayanilo, J. F.; Sparre, P. and Pauly, D. (1997). The FAO-ICLARM Stock Assessment Tools (FiSAT) Reference Manual. FAO Computerized Information Series (Fisheries). Rome, FAO. No. 8, 262 pp.

Gulland, J. A. (1971). The fish resources of the Ocean. West Byfleet, Surrey, Fishing News, Ltd., FAO, 255 pp.

Jones, R. and Van Zalinge, N. P. (1981). Estimates of mortality rate and population size for shrimp in Kuwait waters. Kuwait Bull. Mar. Sci., 2: 273-288.

Khalifa, U. S. and Mehanna, S. F. (2005). Precautionary target reference points (TRPs) for carangid fisheries management in the Gulf of Suez, Red Sea, Egypt. Egyp. J. Aquat. Biol.\& Fish., 10 (1): 139-150.

Le Cren, E. D. (1951). The length-weight relationship and seasonal cycle in gonad weight and condition in the perch (Perca fluviattilis). J. Anim. Ecol., 20: 201219.

Mehanna, S. F. (1999a). Stock assessment of the horse mackerel Trachurus indicus in the Gulf of Suez, Egypt. Indian J. of Fisheries, 46 (4): 327-335.

Mehanna, S. F. (1999b). Population dynamics of the round scad Decapterus macrosoma (Bleeker, 1951) in the Gulf of Suez, Egypt. Egyp. J. Aquat. Biol. \& Fish., 3 (2): 55-68.

Pauly, D. (1980). On the interrelationships between natural mortality, growth parameters and mean environmental temperature in 175 fish stocks. J. Cons. CIEM, 39 (3): 175-192.

Pauly, D. (1983). Length-converted catch curves. A powerful tool for fisheries research in the tropics. Part I. ICLARM Fishbyte, 1 (2): 9-13.

Pauly, D. (1984). Length-converted catch curves. A powerful tool for fisheries research in the tropics. (part II) . ICLARM Fishbyte, 2 (1): 17-19.

Pauly, D and Munro, J. L. (1984). Once more on the comparison of growth in fish and invertebrate. Int. Living Aqua. Res. Manag. Fishbyte, 2 (1): 21p. 
Pauly, D. and Soriano, M. L. (1986). Some practical extensions to Beverton and Holt's relative yield-per recruit model. In: J. L. Maclean, L. B, Dizon and L. V, Hosillo (eds) The First Asian Fisheries Forum, 491-496.

Powell, D. G. (1979). Estimation of mortality and growth parameters from the lengthfrequency in the catch. Rapp. P.-V. Réun. CIEM, 175: 167-169.

Sanders, M. J. and Morgan, G. R. (1989). Review of the fisheries resources of the Red Sea and Gulf of Aden. FAO Fish. Tech. Rep., 304: 1-138.

Ursin, E. (1967). A mathematical model of some aspects of fish growth, respiration and mortality. J. Fish. Res. Bd. Can., 24: 2355-2453.

Wetherall, J. A. (1986). A new method for estimating growth and mortality parameters from length-frequency data. ICLARM Fishbyte, 4 (1): 12-14.

\section{ARABIC SUMMARY}

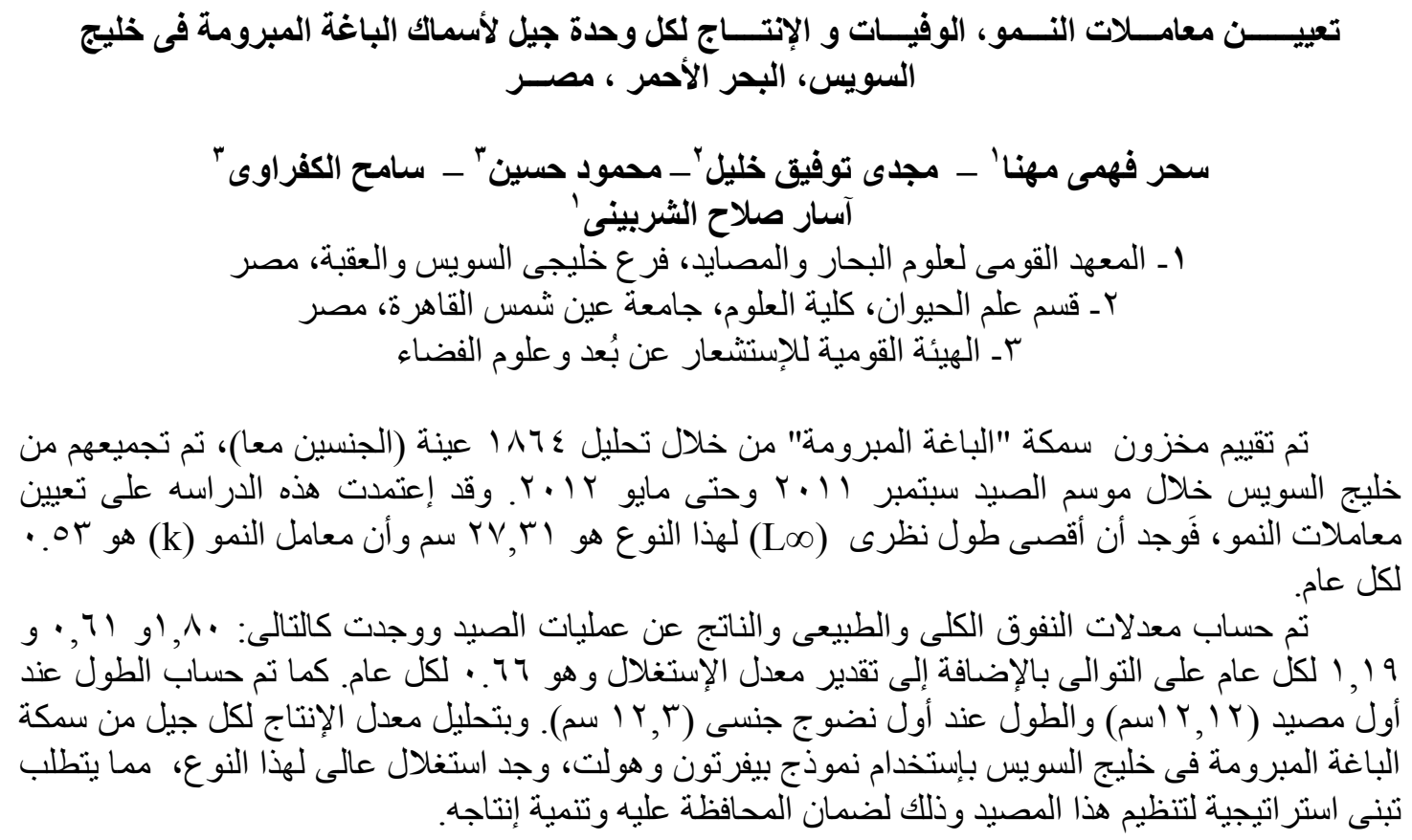

